\title{
The Political Economy of Feminization: From "Cheap Labor" to Gendered Discourses of Work
}

\author{
Teri L. Caraway
}

\section{University of Minnesota, Twin Cities}

Scholars have argued that the feminization of industrial work in developing countries since World War II is primarily a result of women being the cheapest source of labor in the global economy. I argue that scholarship on feminization underestimates the power of gender in labor markets by framing it primarily as an issue of lower wages. This article shows how gendered discourses of work-ideas and practices about men and women providing distinct forms of labor-play a critical role in the feminization process. While agreeing with feminization theorists that competitiveness in export sectors forces employers to reduce production costs, I show that firms and sectors facing similar competitive constraints deploy varied gender divisions of labor in production. Gendered discourses of work not only illuminate processes of job allocation and reallocation at the firm level but also provide a means of connecting shop-floor gender divisions of labor with broader gendered patterns of industrialization and help to explain puzzling empirical patterns. They are as important as, and in some cases more important than, wages. By tracing the processes through which work is gendered and regendered, the analysis opens the black box of feminization and shows how changes in industrialization policy set in motion gendered transformations that ultimately resulted in the feminization of manufacturing work in Indonesia.

I would like to thank the editors of Politics $\&$ Gender and the anonymous reviewers for comments on earlier versions of this article.

Published by Cambridge University Press 1743-923X/05 \$12.00 for The Women and Politics Research Section of the American Political Science Association. (c) The Women and Politics Research Section of the American Political Science Association. Printed in the United States of America.

DOI: $10.1017 / \mathrm{S} 1743923 \mathrm{X} 05050105$ 


\section{INTRODUCTION}

Women workers laboring in export factories present one of the dominant images of globalization. As multinational corporations relocated labor-intensive assembly operations to cheaper production sites overseas, and as export-oriented industrialization (EOI) became an important component of industrialization programs in many developing countries, women began to claim an increasing proportion of industrial jobs (Frobel, Heinrichs, et al. 1980; Joekes 1987; Nash and FernandezKelly 1983). ${ }^{1}$ Scholars have argued that the feminization of industrial work is the inevitable result of the combination of patriarchy, which keeps women's wages low, and EOI (Elson and Pearson 1981; Fox 1993; Joekes 1987; Lim 1983, 1990; Safa 1986). Exporters are drawn to female labor because they must employ the cheapest labor in order to compete in global markets.

In recent years, some scholars have begun to chip away at this argument by highlighting the diversity of gendered labor practices in the global economy (Marchand and Runyan 2000; Razavi 2002; Runyan 2003). The overwhelming focus on women workers in export industries, some argue, has presented a skewed picture of the gendered character of industrialization (Acevedo 1995). Still others have argued that gender divisions of labor in export industries are more diverse than the EOI argument admits (Salzinger 2003). Coming from a perspective influenced by postmodernism, Salzinger's work reveals the varied gendered divisions of labor that have emerged in Mexico's maquiladoras. If global corporate profits depend on access to cheap women workers, then why do varied gender divisions of labor arise in intensely competitive industries?

I argue that most scholarship on feminization underestimates the power of gender in labor markets by framing it primarily as an issue of low wages. This article shows how gendered discourses of work - ideas and practices about men and women providing distinct forms of labor-play a critical role in the feminization process. While agreeing with feminization theorists that competitiveness in export sectors forces employers to reduce production costs, I show that firms and sectors facing similar competitive constraints deploy varied gender divisions of labor in produc-

1. The literature here is too extensive to discuss in detail, but for important book-length studies about women workers in export industries, see Chant and McIlwaine (1995), Cravey (1998), Diamond (1979), Fernandez-Kelly (1983), Heyzer (1988), Joekes (1982), Kim (1997), Kothari and Nababsing (1996), Kung (1994), Lee (1998), Ong (1987), Salaff (1981), Salzinger (2003), Sklair (1993), Tiano (1994), Wolf (1992), and Yelvington (1995). 
tion. Gendered discourses of work not only illuminate processes of job allocation and reallocation at the firm level but also provide a means of connecting shop-floor gender divisions of labor with broader gendered patterns of industrialization. They are as important as, and in some cases more important than, wages. As some have argued, "naturalized assumptions about work and the worker are crucial to understanding the sexual politics of globalization" (Mohanty 1997, 5; see also Peterson 2003).

In the analysis that follows, I draw on both a large data set of firm-level data and extensive fieldwork in factories in Indonesia to elaborate the drawing and redrawing of gender divisions of labor on the shop floor and show how these processes produced feminization. ${ }^{2}$ I define feminization as an expansion of women's share of employment of at least $5 \%$ - changes of this magnitude are large enough to constitute more than a statistical hiccup, and within a sector, a change of that size usually indicates notable gendered changes in the labor process. By tracing the gendering and regendering of work, the analysis addresses the political economy of feminization and shows how changes in industrialization policy set in motion gendered transformations that ultimately resulted in the expansion of women's share of manufacturing work in Indonesia. While feminization gave women increased access to work in manufacturing, feminization was most dramatic in labor-intensive sectors, and gender divisions of labor were reconfigured rather than erased. Since capital-intensive sectors were resistant to feminization, it had a limited impact on the erosion of gender-based inequalities in labor markets.

Since Indonesia underwent feminization during the period 1970-98, it is an appropriate case for assessing the political economy of feminization. Indonesia represents a case of feminization, and as such, other countries that experienced it would provide an equally valid empirical basis for engaging in the theoretical debates surrounding it. My ability to speak

2. The statistical data used in this analysis come from the Statistik Industri Sedang dan Besar (Industrial Survey of Large and Medium Establishments) conducted by the Biro Pusat Statistik (BPS). Only the summary data is available in published form, but I also obtained unpublished firm-level data in a computer file. The survey aims to include all manufacturing plants with more than 20 employees, and in 1996 the survey covered more than 20,000 firms. During field research in 1998-99, I also collected company-level data (wages, absenteeism, turnover, employment, marital status, age, tenure), observed production processes, and interviewed more than 200 supervisors, production managers, and factory heads at more than 50 factories in four sectors - automobiles, textiles, garments, and plywood. I gained entry to factories via the employer organizations in each of these sectors and concentrated my research in regions where the bulk of employment in these industries was located (Jakarta and vicinity for automobiles, textiles, and garments; Bandung for textiles and garments; Solo and vicinity for textiles; and East and West Kalimantan for plywood). Given the large size of the textile and garment sectors, only a small percentage of firms were surveyed. The sample was most comprehensive for automobiles, simply because the sector is dominated by a few large firms. 
Indonesian fluently, of course, permitted me to conduct the in-depth interviews and factory visits on which much of the analysis is based, which is why I chose Indonesia, rather than another country that underwent feminization, as the focus of this study.

\section{GENDERED DISCOURSES OF WORK}

A virtually omnipresent fact of industrial life is the categorization of jobs as "men's work" and "women's work." Men and women seldom perform the same jobs on the shop floor, and one cannot help but be struck by this profound gender segregation upon entering a factory. A constant theme in the literature on women factory workers is that employers associate a number of positive features with female labor that are not reducible to lower wages. I use the concept of gendered discourses of work to capture these ideas that employers hold about men and women workers.

Although scholars studying the massive flow of women into factory work in developing countries address the attributes that I refer to as gendered discourses of work, they integrate them differently into their analysis. ${ }^{3}$ The scholarship that gives gendered discourses of work a causal role in shaping shop-floor divisions of labor usually focuses on a small number of factories and rarely offers theoretical explanations for broader gendered trends in employment. Scholars also seldom trace change over time in gender divisions of labor, even when they pay careful attention to other dynamics on the shop floor. The varying impact of gendered discourses of work on actual divisions of labor is therefore usually overlooked. Those offering theories of feminization, in contrast, rarely incorporate examinations of shop-floor practices of job allocation into their analyses. Although they acknowledge the existence of managerial beliefs about women workers (e.g., docility, dexterity, tolerance for monotony), they place the main causal weight on low wages. Since the causal force of gendered discourses of work are seen as pushing in the same direction as wages, gendered discourses of work are usually subsumed under the wage argument, and the independent causal impact of gendered discourses is lost.

Authors also vacillate between treating gendered discourses of work as managerial subterfuge or as traits that women actually possess (Elson

3. To get a sense of how gendered discourses of work factor into the various studies of women factory workers, see Banerjee (1995), Chant and McIlwaine (1995), Charoenloet and Soonthorndhada (1988), Chhachhi and Pittin (1996), Garnsey and Paukert (1987), Hirata (1989), Kelly (1986), Lie and Lund (1994), and Ong (1987). 
and Pearson 1981; Fernandez-Kelly 1983). For example, at one point Diane Elson and Ruth Pearson argue: "It might seem to follow that the labor force of world market factories is predominantly female because the jobs to be done are regarded as 'women's work.' But to note that jobs are sex-stereotyped is not to explain why this is so. After all, capitalist firms are compelled by competitive forces to select their labor force and constitute their division of labor on the basis of profitability, not ideology" (1981, 92). On the following page, however, the authors note that women's "nimble fingers" are the result of training, and they specifically mention how industrial sewing is similar to sewing in the home on domestic sewing machines (p. 93). Elson and Pearson shift from calling these traits "ideological" to agreeing that women have them and to showing how women obtain them.

I argue that whether women possess these traits is irrelevant; the crucial point is that employers believe that they do. As elegantly stated by Leslie Salzinger, these images are important not because they reflect reality but because they produce it $(2003,9)$. In other contexts, feminist labor historians and sociologists have shown persuasively that gender shapes the way that employers put their economic interests into practice (Downs 1995; Humphrey 1987; Milkman 1987; Rose 1992). These scholars demonstrate that rational economic practice is partially constituted by gender and that employers view productivity and labor control through a gendered lens. Gendered discourses of work are therefore integral to an understanding of the gendered dynamics of hiring practices.

I adopt a synthetic conceptualization of gendered discourses of work, combining a Foucauldian (1990) notion of discourse, R. W. Connell's (1987) praxis-oriented perspective, and poststructuralist feminist approaches (Riley 1988; Scott 1988). I take from Michel Foucault the notion that discourse produces subjects. In this case, the gendered worker on the shop floor is created in part through the discourses produced by management about gendered workers. From a Foucauldian perspective, the issue is not whether women are patient, disciplined, and diligent, but that the subject of the woman worker as a patient, disciplined, and diligent worker is produced through discourse. Poststructuralist feminists have shown the utility of paying attention to how gendered subjects are constructed relationally through discourse, often in the form of binary oppositions. Male and female workers are produced relationally through a series of binary oppositions - for example, careless/careful, lazy/diligent, undisciplined/disciplined, strong/weak, heavy/light. Connell's praxis-oriented approach calls attention to how these discourses, 
once produced, become embedded in institutions and gain materiality, becoming part of the structure of everyday life and shaping relations within it. The importance of binary oppositions and their embeddedness in everyday practice is most evident in the separation of men and women into different job categories in the factory. When these varied approaches to discourse are combined, the contingency of these discourses is acknowledged (they do not represent "truth") and their operation in everyday practice in the factory is integrated into the analysis. Discourse both structures how, and forms a lens through which, subjects in the factory view the labor process; discourse is both created and recreated - and possibly changed-by practice on the shop floor.

Although the factory is a site of the construction of gendered meanings, factories are not free-floating entities. Women are already gendered when they enter the factory, through law, culture, and politics. Gendered discourses in the wider society provide a foundation, or point of linkage, to the gendered discourses of work created in the factory. Given the vast ethnic and cultural diversity in Indonesia, there are a host of societal discourses and practices about gender. ${ }^{4}$ With the formation of a national polity and a national state that molds gender relations through law, public policy, and public pronouncements, however, an Indonesian or national discourse on gender has emerged (Blackwood 1995; Suryakusuma 1987, 6). The outlines of a hegemonic national discourse congealed during the New Order period. ${ }^{5}$

The New Order regime that came to power in the late 1960s adopted a discourse of separate but equal gender roles and emphasized the nurturing and selfless qualities of motherhood over other aspects of women's identities (Djajadiningrat-Nieuwenhuis 1987; Suryakusuma 1987; Tiwon 1996). As Saraswati Sunindyo (1998) points out, although women were also defined as mothers or housewives before the New Order, the regime put the force of the state behind this particular definition. The state expounded on women's "special" role in development as mothers and wives (Caraway 1998; Rahayu 1996; Sen 1998), and state-linked organizations, such as Pembinaan Kesejahteraan Keluarga (PKK) and Dharma Wanita, assured that New Order ideology about women was

4. The immense diversity in gendered practices and discourses in Indonesia is analyzed in Atkinson and Errington (1990).

5. I use Suzanne Brenner's definition of a hegemonic discourse of gender: "models that support the claims of a particular category of people to superior status and power, models which are most likely to be invoked in formal discourse and which are most often accorded a position of supremacy among other, potentially competing models" (1995, 21). 
spread through the programs that they oversaw for the state (Sullivan 1994; Suryakusuma 1987; Wieringa 1993). ${ }^{6}$

A core element of national discourse on women is the term kodrat wanita, which is translated in a variety of ways: biological or female destiny (Sunindyo 1998); the intrinsic nature, true essence, or essential nature of woman (Tiwon, 1996); and women's nature (Wieringa 1993). Kodrat is often associated with the idea that women are soft and weak (lemah lembut) and comes up repeatedly in discussions about the proper roles of women. Kodrat is what makes men and women different in spite of all of their similarities as human beings. Essential difference is embedded in the concept, but the implication of this essential difference is contested and has changed over time. Its existence, however, is rarely challenged. Kodrat forms a bedrock dichotomy between male and female, which gets translated into - and is used to justify - gendered practices in society, including in the factory. The subterranean foundation of gendered discourses of work in Indonesia is kodrat.

During my fieldwork in 1998-99, management generally presented the distinctions between men and women in dichotomous terms and often explicitly justified gender divisions of labor by referring to kodrat. Managers considered women to be more careful, diligent, disciplined, and patient, easier to manage or control, and better suited for light and monotonous work. ${ }^{7}$ Men, in contrast, worked quickly but often carelessly, did not follow orders as well as women, were naughty, ${ }^{8}$ and complained more, but they were better than women at heavy work. I often received tautological answers when asking why women or men did a particular job: "It's women's work," or "It's work that's compatible (cocok) with women," and so on. For certain jobs, some managers were neutral, observing that for that job, either men or women would do, but supervisors seldom mixed men and women in the same jobs because they believed that if men were put in women's jobs (or vice versa), productivity would fall.

6. The PKK penetrated villages and neighborhoods and operated in gendered parallel to the state - the wife of the minister of internal affairs headed the organization at the national level, and at the village level, the wife of the village headman was in charge. It was responsible for carrying out most government programs for women. Dharma Wanita is the organization for female civil servants and the wives of civil servants.

7. My findings about gender divisions of labor and the substance of gendered discourses of work in Indonesia are supported by existing research on female workers in Indonesia. See Andriyani (1989), Grijns et al. (1992), Grijns and van Velzen (1993), Saptari (1995, 2000), Tjandraningsih (1991, 2000), Wolf (1992), and Yusuf (1991).

8. By naughty, managers referred to misbehavior short of serious offenses like stealing. For example, men were more likely to sneak out to have a cigarette, to take long breaks, and to talk back to supervisors. 
Consequently, men and women rarely did the same work, even when they worked in the same area of production; some sections of production were the exclusive preserve of one gender. Since employers viewed jobs in gendered terms, hiring practices were also gendered. Hiring a man for a woman's job would be disruptive, not only because supervisors considered the worker inappropriate for the job but also because most men resented being stuck in a task performed predominantly by women. Management might try out a man in a women's section, either out of curiosity or because of short-term labor shortages, but according to managers, unless the man was "effeminate" he would usually complain or quit. Managers speculated that the men who quit in these situations were embarrassed to do women's work. Other managers observed that men think that they are above doing women's work and would refuse to do it. Still others noted that men doing “women's work" risked being ridiculed and teased by other men. Masculinization of particular types of work usually proceeds in big leaps because enough men need to be placed in a section to give male workers a basis of solidarity.

In most factories, supervisors initiated hiring requests, a process that involved specifying the qualifications of the desired worker. Along with age and education, gender was a key "qualification." The supervisor determined whether the jobs that needed to be filled required male or female labor, and requested the appropriate worker. In other factories, explicit or implicit company policy dictated particular gendered hiring practices. In these cases, supervisors did not need to specify gender on a hiring request, as the personnel department already knew, on the basis of which jobs were open, the number of men or women that had to be recruited. In addition to taking into account education and age, marital status was also an important consideration when hiring women. Employers overwhelmingly preferred to hire single women since they could extract a few years of work out of them before they married and started to have children. However, married women comprised a large proportion of the workforces in many of the factories in my sample because many of them married within a few years of being hired and continued to work after marriage.

Gendered discourses of work not only include factors that help managers decide on the best gendered worker for a job but also encompass broader features of interest to employers. Some managers regarded women as being less likely to go on strike, but most focused less on the propensity to strike and stressed instead that women were easier to control. They emphasized that women followed instructions without delay 
and without talking back, were flexible about doing work outside of their job classifications, stayed at their work stations, and were more punctual than men. The number of strikes rose precipitously in Indonesia in the late 1980s and early 1990s, and many of these strikes occurred in sectors that employed primarily women (Kammen 1997), and so it is unsurprising that many managers considered women to be as prone to strike as men. Managers' perceptions about rates of absenteeism are also important. ${ }^{9}$ For example, if management thinks too many women take maternity leave, then over time they might reduce their reliance on female labor by redefining relatively androgynous job classifications held by women as "men's work."

Why do gendered discourses of work matter for explaining the feminization of manufacturing work? Feminization involves either a gendered redefinition of work - jobs that men previously claimed are redefined as women's work - or the assignment of new jobs to women rather than to men. But what leads employers to change or to establish a particular gender division of labor? I argue that feminization is one method that employers deploy to enhance productivity and labor control. Since gender is a key organizing principle in the factory, managers see productivity and labor control through a gendered lens. For example, if a predominantly male section is producing a lot of poor-quality work, managers may conclude that the work requires more care and patience than men possess, and they solve the problem by replacing men with women. If male workers give supervisors trouble, managers might attribute this to their gender rather than the supervisor's management style or to the stress or monotony of work in that particular section. ${ }^{10}$ Feminization is one method of raising productivity and enhancing labor control.

The structural imperative to remain competitive, however, does not result automatically in specific gendered changes in the labor process. A process of translation must occur whereby managers assess, given the resources at their disposal, how best to deal with the competitive situation that they face. Export-oriented industries, especially in labor-intensive sectors, are more likely to make adjustments to the labor process because they feel the forces of competition most acutely and therefore constantly seek out ways to squeeze more productivity out of their workers. Consequently, rates of feminization are higher in these industries than in more

9. I emphasize perceptions since supervisors had extremely unsophisticated ideas about absenteeism. When asked who had higher absenteeism, they would answer "women" and then explain that this was because most of the employees were women!

10. Specific examples of these dynamics will be given in the case studies that follow. 
capital-intensive and less competitive industries. Wage pressures are important, but they are mediated through gendered discourses of work.

The cheap labor argument is inadequate for two reasons. First, the wage advantages that employers can secure by hiring women instead of men vary from country to country and in some cases are small or nonexistent. ${ }^{11}$ In Indonesia, while women's average wages are lower than men's average wages, this figure does not tell us what workers are actually paid in factories. In the early 1990s, the Indonesian government systematized a minimum wage policy, and minimum wages set by sector and by region became the standard for pay in many industrial sectors (Harrison and Scorse 2004; Manning 1998). ${ }^{12}$ Minimum wages have reduced male-female wage differences within sectors, most notably in labor-intensive sectors. In my factory survey, the ratio of male to female wages was close to one, and in some factories women's average wages exceeded men's, since employers often offered incentive pay to women in exchange for working during their two days of monthly menstruation leave, and since by law women received more generous overtime bonuses for night shifts than men. Hiring women instead of men also incurred other costs. Indonesian law mandates three months of maternity leave with full wages paid by the employer rather than by the state. Many employers evaded payment of maternity leave benefits, of course, but many paid them as well. Employers that paid maternity leave diminished its potential costs by devising elaborate tactics for reducing the number of women who claimed it. They hired young unmarried women, provided family-planning services at factory clinics, and encouraged rapid turnover through a regime of forced overtime, which caused many young women to resign after marriage. All of these strategies carry costs that are only partially reflected in the wage bill, but in spite of these costs, employer interest in hiring women remained keen.

11. Southeast Asia, for example, exhibits a different pattern of gender inequality in wages than East Asia, where male-female pay disparities are extremely large (Bai and Cho 1995). Guy Standing (1996) compared wages in the Philippines and Malaysia and found that wage disparities between men and women for similar classifications of workers were small. The disparity between men's and women's wages in South Korea is one of the widest in the world (Amsden 1989; Standing 1999), yet women constitute a smaller proportion of the manufacturing workforce there than in Southeast Asian countries.

12. Ann Harrison and Jason Scorse's (2004) fascinating study shows that while the level of compliance with the minimum wage varied over time, the overall level of compliance was quite high for a developing country. During the period 1990-99, the compliance level for foreign-owned firms was at least $68 \%$ and usually closer to $80 \%$, while for domestic firms it ranged between about $37 \%$ to $62 \%$. Surprisingly, they also found that firms exposed to global competition were more likely to comply with minimum wage legislation. 
Second, the cheap labor argument cannot explain the variability and the selectivity of the feminization that occurs. Why do some laborintensive export sectors feminize more than others? And why do some factories in the same industry feminize while others do not? To answer this question, we must examine factory-level processes of job allocation and assess how gendered discourses of work shape the cost-benefit analysis that employers engage in when they make decisions about hiring and the allocation of work. Before turning to an analysis of these processes, however, it is first necessary to elaborate in greater depth the broad contours of feminization in Indonesia.

\section{FEMINIZATION IN INDONESIA}

A commitment to economic development was one of the central tenets of the New Order regime that came to power in the late 1960s. After eliminating the Communist Party and other potential opposition, President Suharto restructured Indonesia's economy to make it more appealing to investors (Winters 1996). He christened himself Bapak Pembangunanthe Father of Development - and set out to distinguish himself from the previous regime, which had failed to foster economic stability, much less growth. In the late 1960s, Indonesia was one of the least industrialized countries in the world for its size (Hill 1990a), and manufacturing employment in medium and large firms totaled only about 840,000 workers (Biro Pusat Statistik 1972). The Suharto regime sought to quicken the pace of economic growth, which led the regime to pursue a variety of new economic policies. Industrialization in Indonesia during the New Order can be divided into three major stages: import-substitution industrialization (ISI) (1968-78), the transition period (1979-86), and EOI (1987-97). ${ }^{13}$

During the first stage, ISI, the regime promoted manufacturing industries that produced primarily for the local market and relied mainly on oil revenue for foreign exchange. Capital-intensive sectors expanded most rapidly, and so employment generation was unimpressive, with employment in medium- and large-scale manufacturing increasing by only 130,000 workers during the 1970s (Biro Pusat Statistik 1972, 1981). In the transition phase, the regime reacted to a foreign exchange crisis by devaluing the rupiah and encouraging local investors in a number of labor-intensive sectors, such as garments, textiles, furniture, and ply-

13. This categorization is my own. For a more detailed analysis of the changing structure of Indonesian manufacturing, see Hill (1990a, 1990b, 1992). 
wood, to expand into the export market (Barr 1998, 9; Hill 1991). Domestic investors took the bait, and employment in these sectors of manufacturing began to grow rapidly (Biro Pusat Statistik 1981, 1986).

As oil exports became a less reliable source of foreign exchange, the Indonesian government intensified its efforts to promote export industries in the mid-1980s. The liberalization of imports in May 1986 and a $31 \%$ devaluation of the rupiah in September were the first major steps that set Indonesia on the EOI path. More extensive liberalizations of both trade and investment regulations took place over the next two years. ${ }^{14}$ These policies made Indonesia increasingly attractive to foreign investors, and led not only to more remarkable export performance by industries that had already begun to prove their exporting mettle, but also to the rise of footwear and electronics as major new exporters. Employment in labor-intensive export sectors boomed, doubling between 1985 and 1990 from just over 700,000 workers to over 1.4 million (Biro Pusat Statistik 1986, 1991). About 700,000 more jobs were added in these sectors between 1990 and 1995 (Biro Pusat Statistik 1991, 1996). Although employment growth in the labor-intensive sectors outpaced that in capitalintensive sectors, the most capital-intensive also posted impressive gains.

Wider developments in society and politics facilitated the flow of women into factory work. Women's educational levels and labor force participation rates were rising (Oey-Gardiner 1993), and fertility rates were falling (Gertler and Molyneaux 1994). Employers reported in interviews that the ban on night work for women began to be enforced less strenuously in the late 1970s. ${ }^{15}$ State discourse on women, moreover, increasingly supported women's economic participation. Until the 1980s, the state had stressed women's "special" role in development as mothers and wives, but in the 1980s, new emphasis was placed on women's role as a human resource in the economic sphere (Caraway 1998; Manderson 1980; Rahayu 1996; Sen 1998; Sullivan 1991, 1994; Suryakusuma 1987; Wieringa 1993). This change in government discourse was provoked in part by the increased interest of international organizations in promoting gender equality and women's role in development. By 1988, the national economic policy statement called for an upgrading in women's skills and education to enable them to take advan-

14. For a brief list of the various liberalization measures, see Winters (1996, 156-57).

15. The BPS firm-level data show that women commonly worked on night shifts. In most sectors, there is little difference in women's share of employment between one-shift, two-shift, and threeshift factories. If prohibitions on night work were a significant factor in determining women's employment, one-shift factories should employ more women than three-shift factories. 
tage of work opportunities (Sen 1998). Islamic religious authorities, moreover, largely stood by as women flowed into the workforce.

Shifts in industrialization and a social and political environment that placed few restrictions on the exploitation of female labor combined to generate an impressive wave of feminization. When Indonesia embarked on its industrialization drive in the early 1970s, men held the majority of jobs, but by the mid-1990s, men and women each composed about half of the production workforce (see Table 1). In 1971, only 3 out of 25 sectors employed more women than men (tobacco, garments, and other). Over the next 25 years, women's share of the production workforce increased in most sectors, and women became the majority in 6 additional sectors (textiles, footwear, other chemicals, plastic, electronics, and professional/scientific equipment). As feminization theorists have argued, EOI was an important factor driving this transformation. While ISI concentrated investment in relatively capital-intensive sectors and generated little employment growth, EOI favored labor-intensive industries and created enormous job growth. The labor-intensive sectors that were the major success stories of EOI, such as footwear, garments, textiles, and woodbased industries, generated much of the new employment for women. As would be expected by feminization theorists, feminization of the greatest magnitude occurred in sectors with high and medium-high levels of labor intensity, particularly in those that were major exporters.

This gendered transformation, however, is both much deeper and more varied than the EOI narrative suggests. First, while many export sectors were female intensive, this does not hold true across the board. For example, wood industries were overwhelmingly export oriented and very labor intensive, yet men remained the majority in these industries. Even more surprising, the most female-intensive industry in Indonesia was an inward-oriented and relatively capital-intensive sector, tobacco. Second, even among labor-intensive export industries, the degree of feminization that took place varied dramatically. Thus, while significant feminization took place in both textiles and wood-processing industries, the change in women's share of employment was greater in wood products $(38 \%)$ than in textiles (20\%). Third, even when controlling for exporting and labor intensity, women's actual share of employment varied widely. For instance, women were a higher proportion of the workforce in footwear than in wood products, even though both industries were extremely labor and export intensive. Fourth, the scope of feminization extended far beyond export sectors. A quick glance at Table 1 demonstrates that feminization affected almost every sector of manufacturing. And finally, as I 
Table 1. Gendered changes in industrial employment in Indonesia by level of labor intensity, 1971 and 1996

\begin{tabular}{|c|c|c|c|c|c|c|c|}
\hline Sectors by labor intensity & $\begin{array}{c}\text { Prod. Workers } \\
1971\end{array}$ & $\begin{array}{c}\% \text { Female } \\
1971\end{array}$ & $\begin{array}{c}\text { Prod. Workers } \\
1996\end{array}$ & $\begin{array}{c}\text { \% Female } \\
1996\end{array}$ & $\begin{array}{l}\text { Change in } \\
\text { Employment }\end{array}$ & $\begin{array}{l}\text { Change in } \\
\% \text { Female }\end{array}$ & Trend \\
\hline \multicolumn{8}{|l|}{ Low } \\
\hline Transportation & 4,742 & 2 & 102,039 & 11 & 97,297 & 9 & Feminization \\
\hline Non-ferrous metal products & 0 & 0 & 13,645 & 7 & 13,645 & - & - \\
\hline Iron and steel & 0 & 0 & 25,565 & 1 & 25,565 & - & - \\
\hline \multirow[t]{2}{*}{ Industrial chemicals } & 3,650 & 42 & 45,362 & 19 & 41,712 & -23 & Masculinization \\
\hline & & & \multicolumn{2}{|c|}{ Average increase } & 44,555 & -7 & Masculinization \\
\hline \multicolumn{8}{|l|}{ Medium Low } \\
\hline Tobacco/cigarettes & 151,372 & 77 & 199,053 & 87 & 47,681 & 10 & Feminization \\
\hline Beverages & 4,161 & 26 & 17,655 & 39 & 13,494 & 13 & Feminization \\
\hline Paper & 6,730 & 25 & 70,810 & 22 & 64,080 & -3 & Little change \\
\hline Other chemicals & 22,029 & 48 & 82,287 & 56 & 60,258 & 8 & Feminization \\
\hline Nonmetallic mineral products & 17,593 & 24 & 153,031 & 26 & 135,438 & 2 & Little change \\
\hline Nonelectric machinery & 2,473 & 0 & 34,156 & 8 & 31,683 & 8 & Feminization \\
\hline \multirow[t]{2}{*}{ Electronic equipment" } & 4,048 & 45 & 138,991 & 59 & 134,943 & 14 & Feminization \\
\hline & & & \multicolumn{2}{|c|}{ Average increase } & 69,654 & 7 & Feminization \\
\hline \multicolumn{8}{|l|}{ Medium High } \\
\hline Food & 275,309 & 28 & 394,747 & 45 & 119,438 & 17 & Feminization \\
\hline Textiles* & 145,190 & 36 & 542,296 & 56 & 397,106 & 20 & Feminization \\
\hline Wood processing" & 15,574 & 0 & 344,031 & 38 & 328,457 & 38 & Feminization \\
\hline Printing and publishing & 13,487 & 19 & 53,711 & 31 & 40,224 & 12 & Feminization \\
\hline Rubber ${ }^{* 4}$ & 134,931 & 25 & 90,329 & 24 & $-44,602$ & -1 & Little change \\
\hline Fabricated metal products & 16,259 & 9 & 135,833 & 21 & 119,574 & 12 & Feminization \\
\hline \multirow[t]{2}{*}{ Professional/scientific equip. * } & 47 & 0 & 13,860 & 65 & 13,813 & 65 & Feminization \\
\hline & & & \multicolumn{2}{|c|}{ Average increase } & 139,144 & 23 & Feminization \\
\hline \multicolumn{8}{|l|}{ High } \\
\hline Garments* & 1,553 & 55 & 353,895 & 78 & 352,342 & 23 & Feminization \\
\hline Leather & 1,999 & 8 & 22,963 & 48 & 20,964 & 40 & Feminization \\
\hline Footwear ${ }^{*}$ & 1,927 & 7 & 280,016 & 78 & 278,089 & 71 & Feminization \\
\hline Wood products & 3,987 & 4 & 139,544 & 30 & 135,557 & 26 & Feminization \\
\hline Plastic & 5,394 & 44 & 145,957 & 51 & 150,563 & 7 & Feminization \\
\hline \multirow[t]{2}{*}{ Other manufacturing (incl. toys)* } & 8,329 & 63 & 64,804 & 70 & 56,475 & 7 & Feminization \\
\hline & & & \multicolumn{2}{|c|}{ Average increase } & 163,998 & 29 & Feminization \\
\hline
\end{tabular}

*Indicates that the sector is export intensive.

Source: Biro Pusat Statistik, Statistik Industri Sedang dan Besar (1971, 1996). 
will show, the extent of feminization within sectors was often uneven, with some firms feminizing and others sticking with men. In sum, even when controlling for labor intensity and exporting, sectors and firms within sectors varied both in terms of women's share of employment and in terms of changes over time in the share of employment, and even sectors that were relatively shielded from international competition feminized. I argue that in order to understand both the broad contours of feminization and the variability of its enactment, gendered discourses of work must be integrated into the analysis, and careful attention must be given to factory-level processes of job allocation.

\section{GENDERED DISCOURSES OF WORK AND FEMINIZATION IN THE TEXTILE INDUSTRY}

Gendered discourses of work are fundamental to gendered transformations of work at the plant level. A precondition for feminization is that managers construct or reconstruct gender divisions of labor in a way that channels work to women. But why do employers make particular gendered hiring decisions, and what leads them to change existing gender divisions of labor? Although gendered processes were at work in all four sectors in which field research was conducted, due to space limitations I will analyze two contrasting cases in one industry, weaving.

In 1971, women composed $37 \%$ of production workers in the weaving industry (Biro Pusat Statistik 1972), but over the next 25 years, the weaving industry underwent feminization, and by 1996 , women held $52 \%$ of the production jobs (Biro Pusat Statistik 1997). Although feminization took place in a number of job categories, the feminization of work on the looms accounts for most of it. Existing scholarship on the weaving industry in Indonesia shows that in the 1960s and 1970s, men were commonly found on the looms (Hardjono 1990; Manning 1979; Willner 1961). In my sample of 10 weaving factories in Central and West Java, 6 were established before 1975, and all but 1 employed men on the looms at that time. By 1998, 7 of the 10 factories employed primarily women on the looms, 2 used mostly men, and only 1 relied exclusively on men. In the middle to late 1970s, some employers began to experiment with using women in some sections of production, and more and more concluded that women could do much of the work in weaving factories, most notably jobs on the looms. ${ }^{16}$

16. Interview with factory manager, Bandung, 30 March 1999, and spinning/twisting manager, Bandung, 8 April 1999. 
Although feminization was widespread, factories adopted widely divergent gender divisions of labor. ${ }^{17}$ Even feminizing employers were reluctant to place women in certain areas of production, and some firms did not feminize at all. Factories branched onto one of two paths - a feminizing and a nonfeminizing path. Two examples, Femitex, which feminized, and Machotex, which did not feminize, illuminate how gendered discourses of work play a role in the allocation of work at the plant level. Feminization occurred at Femitex because managers identified a gendered solution to productivity and labor-control problems while at Machotex, managers did not feminize because they doubted that changing the gender division of labor would enhance productivity or simplify labor control.

Femitex, an Indonesian-owned weaving factory in Bandung, employed primarily men when it began production in $1968 .{ }^{18}$ At Femitex, the opposition between female/male was expressed in a series of binary oppositions - easy to control/rebellious, light/heavy, patient/impatient, careful/careless - and managers placed women and men in jobs that they considered to best match their respective gendered attributes. Managers also thought gender affected how workers responded to different wage systems, with men working faster than women under piece-rate conditions and women putting in a relatively consistent level of effort regardless of the payment system.

As in all weaving factories, the loom operator job absorbed the most labor. Work on the semiautomatic looms required some physical stamina, and since the weaver had to carry the finished product to the warehouse, managers considered the work on the looms to be heavy and thus more appropriate to men. In addition, since pay was based on a piecerate system, management favored hiring men, as under this method of payment they believed that men would produce more than women. The piece-rate system, however, generated high levels of conflict between workers and management, since wages were cut for product that did not meet quality standards. Management developed extremely negative opinions about male workers. The factory manager noted that "men cut work, are naughty, aggressive, and more likely to strike." 19 Management was dissatisfied with male workers, but as long as semiautomatic and manual

17. Verdi Yusuf's (1991) research around Bandung also found wide disparities in gender divisions of labor between textile factories.

18. I have hidden the identities of both the companies and the individuals interviewed at the request of the companies that participated in the research.

19. Author interview with factory manager, Bandung, 30 March 1999. 
looms were used, with payment based on a piece-rate system, they were reluctant to employ women on the looms.

In 1973, the introduction of new automatic weaving machines opened the door for a gendered solution to management's labor-control problem. The quantity of production on automatic looms depended less on the diligence and stamina of the operator, and so the company abolished the piece-rate system and initiated a daily wage system. Under a daily wage system, managers thought that women would be more consistent workers than men, and since the looms were automatic, less physical strength was required. After weighing their options, management concluded that replacing men with women would probably not negatively affect productivity and that labor control would be easier. As stated by the factory manager, "Men's production is more than women's, but not by much, and the quality is about the same. But men are naughty so we put women on the new machines and replaced the men in stages on the old machines." ${ }^{20}$ Management therefore readily attributed problems of labor control to the gender of the workers filling the jobs, even though shifting work from men to women carried some significant short-term costs. Men had more experience than women in operating looms, and hiring women required investing time and resources into training a new workforce. Managers also did not consider the possibility that much of the labor conflict was a product of the piece-rate system of payment, rather than the gender of the workers, and that men might be more docile if their pay was not tied directly to the amount produced.

Even though men were considered to be more troublesome and women easier to control, this belief did not lead to a wholesale replacement of men with women. As stated by the head of the weaving section, "The most important thing is that women be placed in work that is in line with their kodrat." ${ }^{21}$ Management considered women to be appropriate only for work that was light and that required patience and attention to detail. Feminization was therefore selective and occurred only in areas of production in which management regarded women to be equally or more productive than men. For example, management never feminized the sizing section, and they continued to use men to carry things between sections of production, because they thought this work was too heavy for women to perform as well as men.

20. Ibid.

21. Author interview with weaving manager, Bandung, 30 March 1999. 
In the 1980s, however, management did feminize an additional section of production, warping: "Men's work performance was poor so we replaced them with women, and the results were better." ${ }^{22}$ A supervisor further explained that "warping work requires patience and care, so it is really more appropriate to women." ${ }^{23}$ Whether women are really more productive or obedient than men is beside the point. Rather, the fascinating dynamic that merits attention is that management attributed individual traits - whether positive or negative - to the gender of the worker. When productivity in warping declined, instead of developing general ways to make workers more disciplined and productive in their respective jobs, management replaced men with women. In the early 1970s, women were only $20 \%$ of the workers at Femitex, but by the end of the 1980s, women claimed about $75 \%$ of the production jobs.

In contrast to Femitex, Machotex enacted few, if any, changes in the gender division of labor in their factory complexes in two suburbs of Jakarta (Tangerang and Bekasi). Machotex is a locally owned and diversified textile concern established in 1974. In late 1998, they employed an average of $36 \%$ women in the weaving factories, and over the years this percentage has not changed. Like managers at Femitex, those at Machotex also considered women to be more appropriate for light work that required patience and attention to detail, and men to be better suited for heavy work. They were less insistent than managers at Femitex about the rebelliousness of male workers, and most managers simply highlighted that women tended to follow orders more quickly than men and were more flexible about doing work outside of their job description. The main difference between Femitex and Machotex was thus not the gendered discourses themselves, but the linking process between these discourses and the jobs in the factory.

At Machotex, managers classified machines as either heavy or light, and then within the jobs categorized as being light, they distinguished between those requiring greater attention to detail and those that demanded less intensity of concentration. They then assigned the appropriate gendered worker to the job. This linking process led to a dramatically different gender division of labor at Machotex than at Femitex. Unlike the managers at Femitex, those at Machotex considered the work on the looms to be heavy, even though the looms were fully automatic, since the operator had to stand for long periods of time and supervise a

22. Ibid.

23. Author interview with weaving superviser, Bandung, 30 March 1999. 
number of machines that ran continuously. They therefore preferred to hire men as loom operators. Women were overwhelmingly concentrated in the inspecting, warping, and reaching jobs, all of which were considered to be light and to require great attention to detail. When I mentioned to one manager that many factories used women on the looms, he nodded but replied that he would only take women if "forced" to do so by upper management. ${ }^{24}$

Managers at Machotex were also reluctant to hire more women because they doubted that women were cheaper to employ than men. Menstruation leave and higher premiums on the night shift made women more costly to employ, and since pregnant women were not allowed to work at night, pregnancies caused scheduling problems in the rotating shift system. ${ }^{25}$ However, management was more than willing to put up with these drawbacks in sections where they deemed that women's special talents resulted in significant productivity advantages in comparison to men: "Women do have more costs associated with employing them, but we weigh that against their strengths, such as patience and attention to detail." ${ }^{26}$ Given that management viewed women to be more expensive to employ, it is unsurprising that on occasion, they experimented with using men in women's jobs, but all of these experiments were deemed to be failures. In the inspecting section, one manager recalled that "we tried out men in inspecting but a lot of flawed material got through, so we decided to stick with women, who are more patient and better at catching defective fabric." 27 The failure of these particular men to perform well in these jobs was immediately attributed to the gender of the worker, rather than to the individual worker's shortcomings.

The gender division of labor thus remained ossified for more than 20 years at Machotex. A necessary precondition for feminization, then, is that managers identify hiring women for particular job categories as improving productivity and/or labor control, and this decision is profoundly shaped by gendered discourses of work. Although intense competition, especially in labor-intensive sectors, increases the probability that feminization will occur, employers that face cutthroat competition do not necessarily conclude that hiring women will give them a competitive edge. Feminization is only one conceivable solution to the problems of productivity and labor control that employers face. Indeed, these two

24. Author interview, weaving manager, Tangerang, 3 January 1999.

25. Author interviews with managers, Bekasi, 1 March 1999.

26. Author interview, finishing supervisor, Tangerang, 3 January 1999.

27. Author interview, weaving manager, Tangerang, 3 January 1999. 
firms confound the conventional wisdom about feminization. Femitex exported little of its production, yet it feminized, whereas Machotex exported nearly all of it but adopted no changes in the gender division of labor and continued to employ primarily men. These differences can only be understood by viewing gendered discourses of work as an integral part of the process through which employers make decisions about hiring.

By integrating gendered discourses of work into the analysis, otherwise puzzling practices become intelligible. Why did Femitex not feminize its entire workforce, given that men were considered to be more troublesome than women? Femitex limited the scope of feminization to jobs that it deemed that women performed as well as or better than men; even though men were harder to control, this disadvantage had to be tolerated in jobs in which men's productivity was thought to be much higher than women's. Why did Machotex, in spite of its exposure to global competition, eschew hiring more women? Because they thought that women were more expensive to hire than men, that women were not significantly easier to control than men, and because much of the work was deemed too heavy for them to perform as well as men. Why did Machotex hire some women, even though they considered them to be more costly than men? They hired women in the job categories in which women were thought to be more productive than men. As the two case studies show, the gendered cost-benefit analysis that managers engaged in is far more complex than conveyed by current theorizing of feminization. Wages are only one consideration that managers take into account, and even when they do, women may not be framed as "cheap labor" but rather as "protected labor" that incurs costs that employers are reluctant to bear.

Let us now turn to an analysis of broader gendered dynamics in the Indonesian political economy that contributed to feminization.

\section{GENDERED DYNAMICS: FOREIGN INVESTMENT, STICKINESS, SPILLOVER, AND SNOWBALLING}

Factory-level processes of feminization are crucial to macrolevel outcomes of feminization, but there were other gendered forces at work that contributed to the depth, breadth, and variability of the feminization process in Indonesia. In this section, I highlight some broader dynamics that contributed to feminization there. These factors include the inflow of significant foreign investment from East Asia and three interrelated 
Table 2. Share of total employment in foreign-owned firms

\begin{tabular}{lc}
\hline Sector & $\begin{array}{c}\text { Percentage of employment } \\
\text { in foreign-owned firms } \\
\text { (Production Workers) }\end{array}$ \\
\hline Garments & $23 \%$ \\
Footwear & $44 \%$ \\
Electronic components & $69 \%$ \\
\hline
\end{tabular}

Source: BPS, Statistik Industri Sedang dan Besar (1996).

dynamics: stickiness, spillover, and snowballing. Gendered discourses of work are important in all of them.

In the 1980s and early 1990s, rising production costs in the East Asian newly industrializing countries (NICs) led investors from these countries, as well as from Japan, to shift many of their labor-intensive operations to Southeast Asia. Investment from NICs surged in Indonesia and by 1990, they accounted for 30\% of approved investments in terms of value and 58\% of approved projects (Wells and Warren 1979; Wie 1991). This investment flowed overwhelmingly into labor-intensive and export-oriented manufacturing (Wie 1991). Foreign investors from Asia accounted for a large share of total employment in footwear, garments, and electronic components (see Table 2), and in these sectors, women on average comprised a larger proportion of the manufacturing workforce in foreign-owned than in domestically owned enterprises. ${ }^{28}$ Koreans dominated in the footwear and garment industries, and Taiwanese investors also had a notable presence in garments. In electronic components, Singapore was the largest foreign investor, followed by Taiwan and Japan. Since there were few local restrictions on the use of female labor, foreign investors were free to deploy their preferred gendered hiring practices in Indonesia. Although Indonesian employers in these sectors also hired primarily women, this dynamic is worth noting for comparative purposes. Foreign direct investors can inject a new gendered dynamic into economies when they adopt different gender divisions of labor than do local producers. The degree of femi-

28. Investment from Western countries was negligible in these sectors. Women's share of employment in these three sectors varied among foreign investors from East Asia as well, but they all hired more women than Indonesian employers. This holds true even when controlling for timing. For example, women comprised a higher proportion of workers in NIC firms established under EOI than in Indonesian firms that began production during EOI. 
nization would have been lower in Indonesia without the influx of foreign investors who came equipped with their own gendered visions about the best workers for jobs in these industries.

In addition to the impact of foreign investment, other gendered dynamics emerged as feminization unfolded in Indonesia - stickiness, spillover, and snowballing. As noted in the weaving case study, some factories bucked the feminization trend. This resistance to feminization, which I call stickiness, would be surprising to most theorists of feminization, but it is not so shocking if we take into account that feminizing is often a difficult process for established firms. First, the division of labor is rooted in deeply held practices about the relative productivities of men and women in specific jobs. The example of other firms that have successfully feminized is not necessarily enough to convince managers that hiring more women is a sensible move. Gender divisions of labor can therefore be quite persistent. Second, even if management decides to feminize, shifting work from men to women in jobs that involve a large number of workers takes time because employers are usually unwilling to fire the entire male workforce and must therefore wait for men to resign. Managers are often reluctant to place women in men's jobs while men are still doing the work, as men seldom welcome women into their realms of activity on the shop floor. Feminization was therefore easiest in firms that expanded, since employers could transfer men from jobs that they wanted to feminize to positions still deemed to be "men's work" in the new unit of production. New factories, in contrast, could hire women from the beginning. Given that gender divisions of labor are sticky, older firms should have lower shares of women workers than newer firms.

The firm-level data from the Biro Pusat Statistik (BPS) industrial survey support this argument. Factories that began production during the ISI period tend to be more male intensive today than the firms established during EOI, even though in most cases, even the ISI firms employ on average a higher percentage of women now than in the past. Figure 1 represents employment in a number of sectors according to when production began. The chart shows that the footprint of the past is still evident. Although older firms have feminized - that is, women comprised a larger proportion of employees in 1996 than in the 1970s - they still employed a lower proportion of women in their workforces than the factories established during EOI. This pattern even holds for inward-oriented sectors such as food that underwent explosive growth in the 1980s and 1990s. The newer firms were relatively free of the "sticky" legacy of the gender division of labor, and if they desired, could (and many did) start with a 


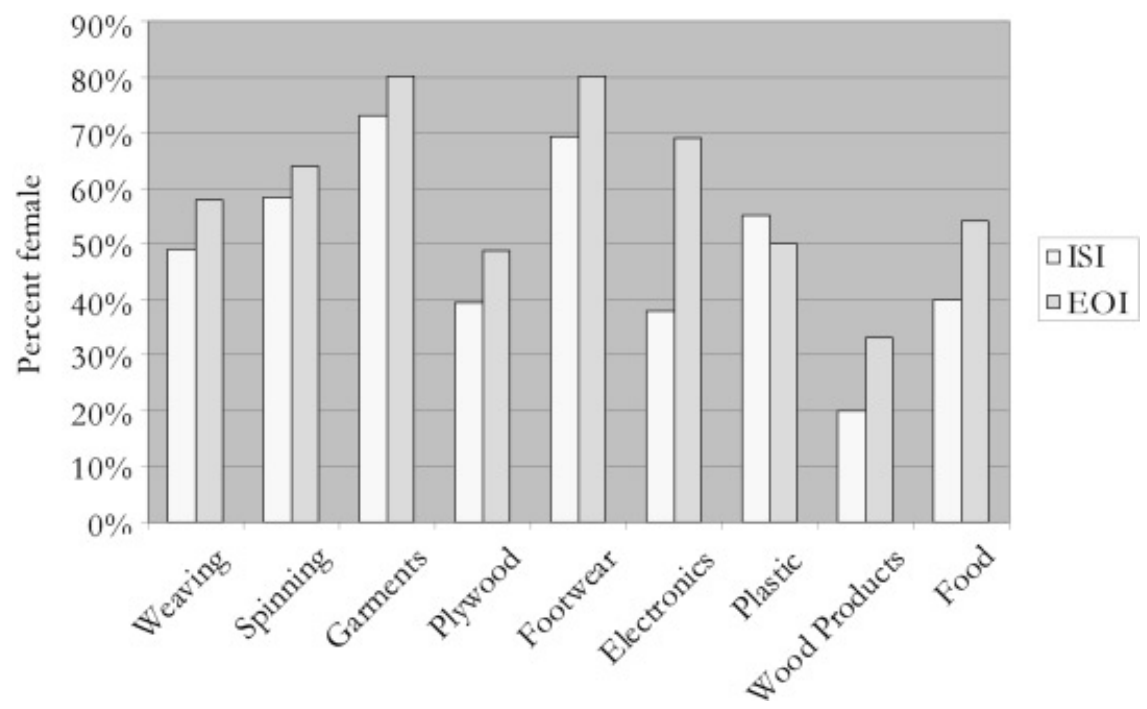

Figure 1. Percent female by phase of initial investment. (Source: Industri Statistik Sedang dan Besar, computer file [1996]).

majority female workforce. As a result of this stickiness phenomenon, employment growth, through both the expansion of existing firms and the opening of new firms, is a prerequisite for significant feminization. ${ }^{29}$

While stickiness slows down feminization, spillover and snowballing help drive the feminization process forward. Spillover captures the dynamic through which practices in a firm or in a sector influence those in another. Firms that feminized in the late 1970s and in the early and middle 1980s played an important role in later feminization, since they upset the association of many kinds of work with male labor. The most common reason employers give for hiring women is that “it's women's work" - but the 1971 statistics and the evidence presented in the case study show that in many instances, men used to do much of this work. These new employers could only consider the work to be women's work because of the earlier feminizers. Investors in later years were more likely to use women from the beginning, as the early feminizers had already shown that it was possible and profitable to hire women.

Spillover works in a number of ways. The first is simply by following common practices in the industry. For example, if new local investors

29. The stickiness phenomenon applies regardless of the origin of investment. In firms that began production before 1980, both foreign and domestic investors tend to employ fewer women than those established after 1986. 
enter into a specific industrial terrain, they will observe the practices of other firms in the area to get a sense for how they want to set up their businesses. Moreover, they will hire experienced managers who know about labor practices in the industry. If many existing firms already employ a lot of women, the chances that this practice will be replicated are high. Second, managers copy new practices that are perceived to be successful. A number of managers in textiles confessed to me that they had experimented with using women in additional areas of production on the basis of the knowledge that their competitor had successfully employed women in those jobs. Third, spillover can also work through the transfer of management from one factory to another, both within a larger group and between companies. For example, at one of the plywood factories in the sample, a manager who was transferred from another factory in the group surveyed the gender division of labor soon after his arrival and determined that women could do some of the jobs that men performed. He immediately began to feminize these job categories. Fourth, since factories are concentrated in industrial zones, the vision of thousands of women ambling through the factory gates undoubtedly led managers in other industries to consider the possibility of employing women workers as well. The existence of feminization in some sectors makes employers in other sectors more likely to consider shifting selected jobs to women as well. The data in Figure 1 also support this assertion about spillover effects; even though ISI firms feminized, the EOI factories employ more women. Spillover effects can move in either direction - feminization or masculinization - but in a previously maledominated industry, the emergence of many successful feminized firms injects a new dynamic into decisions about the gendering of workforces and makes the choice of women more likely than in the past.

Snowballing takes place when employment grows rapidly in firms that already employ large numbers of women in their workforces. Employment growth in the 1990s was most rapid in female-intensive sectors, and although some of this growth came from newly established factories, much of it was also a result of the expansion of existing firms. Garment factories in Indonesia, for example, often started off as relatively small enterprises that had just one or two assembly lines. As they grew, they added additional sewing lines and expanded the cutting and finishing sections. Since they often already employed at least $80 \%$ women in their workforces, the growth of these firms had a snowballing effect in terms of women's employment. Employment growth therefore not only provides an opportunity to feminize but also allows for the replication of existing practices on a larger scale. 


\section{CONCLUSION}

Incorporating gendered discourses of work into an analysis of feminization both helps to explain empirical anomalies for which the cheaplabor argument cannot account and illuminates the processes through which economic imperatives lead to particular gendered outcomes. Wages are part of the story, but the excessive focus on the wage component of the explanation has led to an underestimation of the extent to which gender infuses capitalist labor practices. Gendered discourses of work provide a means for connecting shop-floor transformations of gendered labor processes with macrolevel gendered outcomes.

A focus on gendered discourses of work highlights the dynamics through which competition produces feminization. Since export- and labor-intensive industries face intense competition, they are under greater pressure to adopt productivity-enhancing alterations to the labor process. Consequently, the probability of feminization taking place is higher in these sectors than in capital-intensive and inward-oriented sectors. Nevertheless, the analysis also shows that global competition in and of itself is not enough to provoke feminization. Femitex, an inwardly oriented firm, feminized, while Machotex, an export-oriented factory, preferred to employ primarily men and abstained from feminization. Employers must be convinced that hiring women will enhance productivity and labor control, and this assessment depends on the qualities they associate with gendered workers and how they link gendered workers to particular jobs. When productivity and labor-control difficulties arise, gendered discourses of work shape how they respond to these problems. Feminization is one, but not the only, solution that managers invent to resolve the challenges that they face. Gendered discourses of work do not lead to neat predictions about which factories will feminize, since it is an interpretive argument, but they help us to explain otherwise puzzling outcomes, such as why some exporters choose not to feminize and why firms that face similar competitive situations adopt dramatically different gendered hiring practices.

Gendered discourses of work not only illuminate the shop-floor dynamics of feminization but also link local and global processes of feminization and provide insights that other scholars have missed. First, they show how foreign investment can potentially increase the magnitude of feminization when they account for a large share of employment in a sector and when they have stronger preferences for hiring women than do local investors. Second, the analysis of gendered discourses of work 
and how they become embedded in production processes illuminates why employment growth is highly correlated with feminization. Employment growth allows existing employers that expand to replace men with women without firing the male workers and allows new employers to simply hire women from the beginning. Feminization is less likely to occur in firms or in economies in which there is no employment growth. Third, the analysis demonstrated how feminization in some factories and sectors generates dynamics that encourage the spread of feminization to other factories and sectors through spillover effects. As such, feminization is rarely confined to just labor-intensive exporters but will spread to numerous sectors in the economy, particularly those that experience impressive employment growth. Fourth, and perhaps most importantly, this article demonstrates that gender is far more deeply rooted in structures of production than the cheap-labor narrative portrays. The cheap-labor argument implies that if gender differences in wages are small, then the allure of women to employers is diminished. Yet in Indonesia, women's share of employment continued to expand, even though women were not always cheaper to employ than men. Coming to grips with how gender shapes capitalist development thus requires a more nuanced and deeply gendered political economy than that prevailing in most existing studies of women workers.

The gendered dynamics of feminization also shed light on the persistence of gender inequality in labor markets. In Indonesia, although women gained access to an increasing array of manufacturing jobs, they were overwhelmingly concentrated in relatively labor-intensive lines of work, and gender divisions of labor on the shop floor were redrawn rather than eliminated. The tenaciousness of gender as a dividing line in production suggests that market forces act to reproduce gender divisions in a slightly altered form, rather than undermine gender as a bedrock category in labor markets. Given that feminization is generated in contexts where employment growth is rapid and in sectors in which competitive dynamics are especially intense, feminization is concentrated in sectors that tend to pay lower wages. Given that capital-intensive employers are less reliant on labor as an input in production-so that employment growth is relatively modest even when they are expanding-and that competition is less intense than in labor-intensive sectors, significant feminization will not occur in the higher-paying capital-intensive sectors. Consequently, even though feminization expands women's integration into manufacturing work, it does not significantly erode women's marginalization in less remunerative lines of manufacturing work. Until the 
gendered discourses of work that undergird gender divisions of labor are overturned, rather than simply reconfigured, feminization promises the mixed blessing of increased integration and continued marginalization.

\section{REFERENCES}

Acevedo, Luz del Alba. 1995. "Feminist Inroads in the Study of Women's Work and Development." In Women in the Latin American Development Process, ed. Christine Bose and Edna Acosta-Belen. Philadelphia: Temple University Press, 65-98.

Amsden, Alice H. 1989. Asia's Next Giant: South Korea and Late Industrialization. New York: Oxford University Press.

Andriyani, Nori. 1989. "Pembagian Kerja Secara Seksual pada Kerja Upahan." Baccalaureate thesis, Sociology. University of Indonesia, Depok.

Atkinson, Jane Monnig, and Shelly Errington, eds. 1990. Power \& Difference: Gender in Island Southeast Asia. Stanford: Stanford University Press.

Bai, Moo Ki, and Woo Hyun Cho. 1995. Women's Wages and Employment in Korea. Seoul: Seoul National University Press.

Banerjee, Nirmala. 1995. "Something Old, Something New, Something Borrowed ... The Electronics Industry in Calcutta." In Women Encounter Technology: Changing Patterns of Employment in the Third World, ed. Swasti Mitter and Sheila Rowbotham. New York: Routledge, 233-55.

Barr, Christopher M. 1998. "Bob Hasan, The Rise of APKINDO, and the Shifting Dynamics of Control in Indonesia's Timber Sector." Indonesia 65 (April): 1-36.

Biro Pusat Statistik. 1972. Statistik Industri Sedang dan Besar 1971. Jakarta: Biro Pusat Statistik.

Biro Pusat Statistik. 1981. Statistik Industri Sedang dan Besar 1980. Jakarta: Biro Pusat Statistik.

Biro Pusat Statistik. 1986. Sensus Ekonomi 1985. Jakarta: Biro Pusat Statistik.

Biro Pusat Statistik. 1991. Statistik Industri Sedang dan Besar 1990. Jakarta: Biro Pusat Statistik.

Biro Pusat Statistik. 1996. Statistik Industri Sedang dan Besar 1995. Jakarta: Biro Pusat Statistik.

Biro Pusat Statistik. 1997. Statistik Industri Sedang dan Besar 1996. Jakarta: Biro Pusat Statistik.

Blackwood, Evelyn. 1995. "Senior Women, Model Mothers, and Dutiful Wives: Managing Gender Contradictions in a Minangkabau Village.” In Bewitching Women, Pious Men: Gender and Body Politics in Southeast Asia, ed. Aihwa Ong and Michael G. Peletz. Berkeley: University of California Press, 124-58.

Brenner, Suzanne. 1995. "Why Women Rule the Roost: Rethinking Javanese Ideologies of Gender and Self-Control." In Bewitching Women, Pious Men: Gender and Body Politics in Southeast Asia, ed. Aihwa Ong and Michael G. Peletz. Berkeley: University of California Press, 19-50.

Caraway, Teri. 1998. "Perempuan dan Pembangunan: Sejarahnya sebagai Lapangan Studi dan Ideologi Pemerintah Indonesia." Jurnal Perempuan 5 (November[1997]-January): 4-14.

Chant, Sylvia, and Cathy McIlwaine. 1995. Women of a Lesser Cost: Female Labor, Foreign Exchange, and Philippine Development. East Haven, CT: Pluto.

Charoenloet, Voravidh, and Amara Soonthorndhada. 1988. "Factory Management, Skill Formation and Attitudes of Women Workers in Thailand: A Comparison between an American and a Japanese Factory." In Daughters in Industry: Work, Skills, and Con- 
sciousness of Women Workers in Asia, ed. Noeleen Heyzer. Kuala Lumpur: Asian and Pacific Development Center, 209-36.

Chhachhi, Amrita, and Renee Pittin. 1996. "Multiple Identities, Multiple Strategies." In State, Capital, and Patriarchy: Women Organizing in the Process of Industrialization, ed. Amrita Chhachhi and Renee Pittin. The Hague: Institute of Social Studies, 93130 .

Connell, R. W. 1987. Gender and Power. Stanford: Stanford University Press.

Cravey, Altha J. 1998. Women and Work in Mexico's Maquiladoras. Lanham, MD: Rowman \& Littlefield.

Diamond, Norma. 1979. "Women and Industry in Taiwan." Modern China 5 (3): 317-40.

Djajadiningrat-Nieuwenhuis, Madelon. 1987. "Ibuism and Priyayization: Path to Power?" In Indonesian Women in Focus: Past and Present Notions, ed. Elsbeth Locher-Scholten and Anke Niehof. Providence, RI: Foris Publications.

Downs, Laura Lee. 1995. Manufacturing Inequality: Gender Division in the French and British Metalworking Industries, 1914-1939. Ithaca, NY: Cornell University Press.

Elson, Diane, and Ruth Pearson. 1981. "The Subordination of Women and the Internationalization of Factory Production." In Of Marriage and the Market, ed. Kate Young, Carol Wolkowitz, and Roslyn McCullagh. New York: Routledge, 18-40.

Fernandez-Kelly, Maria Patricia. 1983. For We Are Sold, I and My People: Women and Industry in Mexico's Frontier. Albany: State University of New York Press.

Foucault, Michel. 1990. The History of Sexuality: An Introduction. New York: Vintage Books.

Fox, Julia D. 1993. "Transformations in the Labor Process on a World Scale: Women in the New International Division of Labor." In The Labor Process and Control of Labor, ed. Berch Berberoglu. Westport, CT: Praeger, 137-51.

Frobel, F., Jurgen Heinrichs, et al. 1980. The New International Division of Labor. New York: Cambridge University Press.

Garnsey, Elizabeth, and Liba Paukert. 1987. Industrial Change and Women's Employment: Trends in the New International Division of Labor, Research Series No. 86. Geneva: International Institute for Labor Studies.

Gertler, Paul J., and John W. Molyneaux. 1994. "How Economic Development and Family Planning Programs Reduce Indonesian Fertility." Demography 31 (1): 33-63.

Grijns, Mies, et al. 1992. Gender, Marginalization and Rural Industries: Female Entrepreneurs, Wage Workers, and Family Workers in West Java. Bandung: PSP-IPB, ISS, and PPLH-ITB.

Grijns, Mies, and Anita van Velzen. 1993. "Working Women: Differentiation and Marginalization.” In Indonesia Assessment_Labor: Sharing in the Benefits of Growth? ed. Christopher Gibson Manning and Joan Hardjono. Canberra: Department of Economics and Department of Political and Social Change, Research School of Pacific Studies, Australian National University, 214-28.

Hardjono, Joan. 1990. Developments in the Majalaya Textile Industry. Bandung: ISSBandung Research Project.

Harrison, Ann, and Jason Scorse. 2004. "Moving Up or Moving Out? Anti-Sweatshop Activists and Labor Market Outcomes.” NBER Working Paper 10492. Cambridge, MA: National Bureau of Economic Research.

Heyzer, Noeleen, ed. 1988. Daughters in Industry: Work Skills and Consciousness of Women Workers in Asia. Kuala Lumpur: Asian and Pacific Development Center.

Hill, Hal. 1990a. "Indonesia’s Industrial Transformation, Part I." Bulletin of Indonesian Economic Studies 26 (2): 79-120.

Hill, Hal. 1990b. "Indonesia’s Industrial Transformation, Part II." Bulletin of Indonesian Economic Studies 26 (3): 75-109. 
Hill, Hal. 1991. “The Emperor's Clothes Can Now Be Made in Indonesia." Bulletin of Indonesian Economic Studies 27 (3): 89-127.

Hill, Hal. 1992. "Manufacturing Industry." In The Oil Boom and After: Indonesian Economic Policy and Performance in the Soeharto Era, ed. Anne Booth. New York: Oxford University Press, 204-57.

Hirata, Helena. 1989. "Producation Relocation: An Electronics Multinational in France and Brazil." In Women's Employment and Multinationals in Europe, ed. Diane Elson and Ruth Pearson. London: Macmillan, 129-43.

Humphrey, John. 1987. Gender and Work in the Third World. London: Tavistock.

Joekes, Susan P. 1982. Female-Led Industrialization: Women's Jobs in Third World Export Manufacturing. Brighton, Sussex: Institute of Development Studies.

Joekes, Susan P. 1987. Women in the World Economy: An INSTRAW Study. New York: Oxford University Press.

Kammen, Douglas. 1997. A Time to Strike: Industrial Strikes and Changing Class Relations in New Order Indonesia. Ph.D. diss. Department of Government, Cornell University, Ithaca.

Kelly, Deirdre. 1986. “St. Lucia’s Female Electronics Factory Workers: Key Components in an Export-Oriented Industrialization Strategy.” World Develoment 14 (7): 823-38.

Kim, Seung-Kyung. 1997. Class Struggle or Family Struggle? The Lives of Women Factory Workers in South Korea. New York: Cambridge University Press.

Kothari, Uma, and Vidula Nababsing. 1996. Gender and Industrialisation: Mauritius, Bangladesh, Sri Lanka. Stanley, Rose-Hill (Mauritius): Editions de L’Ocean Indien.

Kung, Lydia. 1994. Factory Women in Taiwan. New York: Columbia University Press.

Lee, Ching Kwan. 1998. Gender and the South China Miracle: Two Worlds of Factory Women. Berkeley: University of California Press.

Lie, Merete, and Ragnhild Lund. 1994. Renegotiating Local Values: Working Women and Foreign Industry in Malaysia. Richmond, UK: Curzon Press.

Lim, Linda Y. C. 1983. "Capitalism, Imperialism, and Patriarchy: The Dilemma of ThirdWorld Women Workers in Multinational Factories." In Women, Men and the International Division of Labor, ed. June Nash and Maria Patricia Fernandez-Kelly. Albany: State University of New York, 70-91.

Lim, Linda Y. C. 1990. "Women's Work in Export Factories: The Politics of a Cause." In Persistent Inequalities: Women and World Development, ed. Irene Tinker. New York: Oxford University Press, 101-19.

Manderson, Lenore. 1980. "Right and Responsibility, Power and Privilege: Women's Roles in Contemporary Indonesia." In Kartini Centenary: Indonesian Women Then and Now, ed. Ailsa Gwennyth Zainu'ddin. Clayton, Australia: Monash University Press, 69-92.

Manning, Christopher Gibson. 1979. Wage Differentials and Labor Market Segmentation in Indonesian Manufacturing. Ph.D. diss. Australian National University, Canberra.

Manning, Christopher Gibson. 1998. Indonesian Labor in Transition: An East Asian Success Story? New York: Cambridge University Press.

Marchand, Marianne H., and Anne Sisson Runyan, eds. 2000. Gender and Global Restructuring: Sightings, Sites and Resistances. London: Routledge.

Milkman, Ruth. 1987. Gender at Work: The Dynamics of Job Segregation by Sex During World War II. Urbana: University of Illinois Press.

Mohanty, Chandra Talpade. 1997. "Women Workers and Capitalist Scripts: Ideologies of Domination, Common Interests, and the Politics of Solidarity." In Feminist Genealogies, Colonial Legacies, Democratic Futures, ed. M. Jacqui Alexander and Chandra Talpade Mohanty. New York: Routledge, 3-29. 
Nash, June, and Maria Patricia Fernandez-Kelly. 1983. Women, Men, and the International Division of Labor. Albany: State University of New York Press.

Oey-Gardiner, Mayling. 1993. "A Gender Perspective in Indonesia’s Labor Market." In Indonesia Assessment - Labor: Sharing in the Benefits of Growth, ed. Christopher Gibson Manning and Joan Hardjono. Canberra: Department of Economics and Department of Political and Social Change, Research School of Pacific Studies, Australian National University, 3-29.

Ong, Aihwa. 1987. Spirits of Resistance and Capitalist Discipline: Factory Women in Malaysia. Albany: State University of New York Press.

Peterson, V. Spike. 2003. A Critical Rewriting of Global Political Economy: Integrating Reproductive, Productive and Virtual Economies. New York: Routledge.

Rahayu, Ruth Indiah. 1996. "Politik Gender Orde Baru: Tinjauan Organisasi Perempuan sejak 1980-an." Prisma 5 (May): 29-42.

Razavi, Shahra, ed. 2002. Shifting Burdens: Gender and Agrarian Change under Neoliberalism. Bloomfield, CT: Kumarian Press.

Riley, Denise. 1988. Am I That Name? Feminism and the Category of 'Women' in History. Minneapolis: University of Minnesota Press.

Rose, Sonia. 1992. Limited Livelihoods: Gender and Class in Nineteenth-Century England. Berkeley: University of California Press.

Runyan, Anne Sisson. 2003. “The Places of Women in Trading Places Revisited: Gendered Global/Regional Regimes and Inter-nationalized Feminist Resistance." In Globalization: Theory and Practice, ed. Eleonore Kofman and Gillian Youngs. New York: Continuum, 139-56.

Safa, Helen. 1986. "Runaway Shops and Female Employment: The Search for Cheap Labor.” In Women's Work, ed. Eleanor Leacock and Helen Safa. New York: Bergin \& Garvey, 58-71.

Salaff, Janet W. 1981. Working Daughters of Hong Kong: Filial Piety or Power in the Family? New York: Cambridge University Press.

Salzinger, Leslie. 2003. Genders in Production: Making Workers in Mexico's Global Factories. Berkeley: University of California Press.

Saptari, Ratna. 1995. "Rural Women to the Factories: Continuity and Change in East Java's Kretek Industry." Ph.D. diss. Faculty of Politics, Society and Culture, University of Amsterdam.

Saptari, Ratna. 2000. "Production Processes and the Gendering of Industrial Work in Asia." Asian Studies Review 24 (2): 147-59.

Scott, Joan Wallach. 1988. Gender and the Politics of History. New York: Columbia University Press.

Sen, Krishna. 1998. "Indonesian Women at Work: Reframing the Subject.” In Gender and Power in Affluent Asia, ed. Krishna Sen and Maila Stivens. New York: Routledge, 35-62.

Sklair, Leslie. 1993. Assembling for Development: The Maquila Industry in Mexico and the United States. San Diego: Center for U.S.-Mexican Studies, UCSD Press.

Standing, Guy. 1996. "Cumulative Disadvantage? Women Industrial Workers in Malaysia and the Philippines." In Patriarchy and Economic Development, ed. Valentine M. Moghadam. Oxford: Clarendon, 269-302.

Standing, Guy. 1999. "Global Feminization Through Flexible Labor: A Theme Revisited." World Development 27 (3): 583-602.

Sullivan, Norma. 1991. "Gender and Politics in Indonesia." In Why Gender Matters in Southeast Asian Politics, ed. Maila Stivens. Clayton, Australia: Monash Papers on Southeast Asia, 61-86.

Sullivan, Norma. 1994. Masters and Managers: A Study of Gender Relations in Urban Java. New York: Allen \& Unwin. 
Sunindyo, Saraswati. 1998. "When the Earth Is Female and the Nation Is Mother: Gender, the Armed Forces and Nationalism in Indonesia." Feminist Review 58 (Spring): $1-21$.

Suryakusuma, Julia. 1987. State Ibuism: The Social Construction of Womanhood in the Indonesian New Order. Master's thesis, Development Studies. Institute for Social Studies, The Hague.

Tiano, Susan. 1994. Patriarchy on the Line: Labor, Gender, and Ideology in the Mexican Maquila Industry. Philadelphia: Temple University Press.

Tiwon, Sylvia. 1996. "Models and Maniacs: Articulating the Female in Indonesia." In Fantasizing the Feminine in Indonesia, ed. Laurie J. Sears. Durham, NC: Duke University Press, 47-70.

Tjandraningsih, Indrasari. 1991. Tenaga Kerja Pedesaan Pada Industri Besar Sepatu Olahraga Untuk Ekspor. Bandung: ISS-Bandung Research Project Office.

Tjandraningsih, Indrasari. 2000. "Gendered Work and Labor Control: Women Factory Workers in Indonesia." Asian Studies Review 24 (2): 257-68.

Wells, Louis T., and V'Ella Warren. 1979. "Developing Country Investors in Indonesia." Bulletin of Indonesian Economic Studies 15 (1): 69-84.

Wie, Thee Kian. 1991. "The Surge of Asian NIC Investment into Indonesia.” Bulletin of Indonesian Economic Studies 27 (3): 55-88.

Wieringa, Saskia. 1993. “Two Indonesian Women's Organizations: Gerwani and the PKK." Bulletin of Concerned Asian Scholars 25 (2): 17-30.

Willner, Ann Ruth. 1961. From Rice-Field to Factory: The Industrialization of a Rural Labor Force in Java. Ph.D. diss., International Relations. University of Chicago.

Winters, Jeffrey A. 1996. Power in Motion: Capital Mobility and the Indonesian State. Ithaca, NY: Cornell University Press.

Wolf, Diane. 1992. Factory Daughters: Gender, Household Dynamics, and Rural Industrialization in Java. Berkeley: University of California Press.

Yelvington, Kevin A. 1995. Producing Power: Ethnicity, Gender, and Class in a Caribbean Workplace. Philadelphia: Temple University Press.

Yusuf, Verdi. 1991. Pembentukan Angkatan Kerja Industri Garment Untuk Ekspor: Pengalaman Dari Bandung_Jawa Barat. Bandung: ISS-Bandung Research Project Office. 